NBER WORKING PAPERS SERIES

NONRATIONAL ACTORS AND FINANCIAL MARKET BEHAVIOR

\author{
Richard Zeckhauser \\ Jayendu Patel \\ Darryll Hendricks
}

Working Paper No. 3731

\author{
NATIONAL BUREAU OF ECONOMIC RESEARCH \\ 1050 Massachusetts Avenue \\ Cambridge, MA 02138 \\ June 1991
}

Zeckhauser is also affiliated with the National Bureau of Economic Research. Please direct correspondence to 79 JFK St., Cambridge, MA 02138, U.S.A. (phone: 617-495-1393, fax: 617-4951972). The research was partially funded by the Decision, Risk, and Management Science Program of the National Science

Foundation. This paper is forthcoming in Theory and Decision. This paper is part of NBER's research program in Financial

Markets and Monetary Economics. Any opinions expressed are those of the authors and not those of the National Bureau of Economic Research. 
NBER Working Paper \#3731

June 1991

NONRATIONAL ACTORS AND FINANCIAL MARKET BEHAVIOR

\begin{abstract}
The insights of descriptive decision theorists and psychologists, we believe, have much to contribute to our understanding of financial market macrophenomena. We propose an analytic agenda that distinguishes those individual idiosyncrasies that prove consequential at the macro-level from those that are neutralized by market processes such as poaching. We discuss five behavioral traits - barn-door closing, expert/reliance effects, status quo bias, framing, and herding that we employ in explaining financial flows. Patterns in flows to mutual funds, to new equities, across national boundaries, as well as movements in debt-equity ratios are shown to be consistent with deviations from rationality.
\end{abstract}

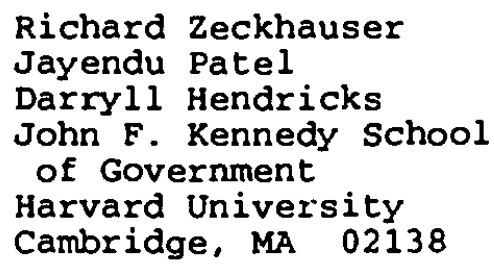




\section{Nonrational Actors and Financial Market Behavior}

Are financial markets efficient? Do their participants behave rationally? Does a positive answer to the second question imply a positive answer to the first? And vice versa? These remain open questions despite decades of effort by economists and numerous claims that the issues have been resolved.

Financial markets are extremely competitive (with near-instantaneous price adjustments and little room for strategic behavior), with virtually no externalities from participants' actions. Under such conditions, individual rationality can aggregate to collectively efficient outcomes. A body of work developing this view was honored by the Nobel Committee in Economics when it awarded its 1990 prize to modern finance's pioneers, Harry Markowitz, Merton Miller, and William Sharpe. But does this paradigm capture most financial market behavior?

Clearly, some of the participants in financial markets do not act with perfect rationality; that is, they make mistakes. ${ }^{1}$ But more astute players stand ready to capitalize on their mistakes - for example, to buy when panic leads to speculative market crashes, to extract $1 / 8 \mathrm{~s}$ and $1 / 4 \mathrm{~s}$ from individuals who trade in and out in the mistaken belief that they can beat the market, or to take positions to bring mispriced stocks into line. Given this sort of "poaching" (which includes arbitrage), the collective outcome may be indistinguishable from the one that would result if all participants behaved with perfect rationality.

Consequently, one might expect to find few instances of nonrational financial behavior at aggregate levels. But then how can we account for speculative fads, from the Dutch tulip mania of the seventeenth century to the rash of junk bonds in the 1980s (see Shiller, 1989)? ${ }^{2}$ Equally puzzling is the crash of October 1987, which reduced the stock market's value by onethird, although no significant bad news had broken. Such events hint that the rationality paradigm may not be universally applicable, but since each case is unique in important respects, their true cumulative significance is difficult to interpret.

Academic attempts to identify inefficient aggregate behavior, or to refute the assumption of a rational representative agent, have focused predominantly on asset prices. Shiller's (1981,

\footnotetext{
${ }^{1}$ For our purposes. a nonratinnal or irrational agent is simply nne who differs frnm the nexclassical hnmo oconomicus prowtype characterized by Von Neumann-Morgenstern utility, optimal expectations. Bayesian updating rules for probability revision. and so on. The yualifier "behavioral." in our paper, is interchangeable with "nonrational," and carries no pejorative connotations.

${ }^{2}$ Bad overall outcomes can result from goxd individual choices as well as from ponr ones. In this spirit. the economist explains various undesirable social phenomena, from unemployment to traffic congestion. as collectively suboptimal outcnmes that result from rational individual choices (Schelling, 1978).
} 
1989) work, arguing that the equity prices are excessively volatile relative to dividend streams, is a hotly debated example. ${ }^{3}$ In this paper, we focus instead on the evidence from financial flows, which like asset prices are regular (not idiosyncratic) and therefore provide a usable database. From a policy standpoint such flows are of vital concern since they represent the investment patterns of our economy. ${ }^{4}$

We will argue that patterns in various types of flows - to mutual funds, to new equities, across national boundaries - are consistent with deviations from rationality. The insights of descriptive decision theorists and psychologists, we believe, have much to contribute to our understanding of such financial market macrophenomena. We propose an analytic agenda that distinguishes those individual idiosyncrasies that prove consequential at the macro-level from those that are neutralized by market processes such as poaching.

The plan of the paper is as follows. Section 1 sketches the current state of the efficient markets paradigm, and contrasts it with behavioral phenomena relevant to the study of financial market outcomes. Section 2 highlights selected empirical results that show these behavioral factors at work. Section 3 discusses further applications of the behavioral approach in finance, and section 4 concludes.

\section{Behavioral foundations of financial macrophenomena}

We focus on behavior as it is revealed in market outcomes, rather than approach our subject through surveys or controlled experiments. ${ }^{6}$ One would expect financial market outcomes to avoid certain kinds of nonrationality that might appear under experimental conditions, because investors play for significant stakes and have sustained opportunities for practice. In experimental markets that permit practice and significant payment, Camerer (1987) has found that many anomalies vanish, although individuals continue to suffer from

\footnotetext{
${ }^{3}$ Also soe the anomalies columns in the Journs/ of Economic Perspectives [Vol. 1, 1987, and subsequent issues], and references in Lerny, 1989, section VII.

${ }^{4}$ The finance academy sheepishly acknowledges the relative lack of work on this topic. For example, Ross (1989, p. 94) admits that "there can be nothing more embarrassing to an economist than the ability to explain the price in a market while being completely silent on the quantity." He suggests that the only way to explain the volume of financial trade is with a model that, while rational, permits divergent and changing opinions.

${ }^{5}$ Patel, Zeckhauser, and Hendricks (1991a) briefly review a portion of the material discussed here.

${ }^{6}$ We sidestep the philosiphical dehate on whether models should be judged hy the realism of their assumptions or the accuracy of their predictions - for instance, sece Friedman (1953) and the vast subsequent literature. In the present context, this debate would focus on whether good models must make realistic assumptions about individual behavior. or need only make accurate predictions about aggregate outcomes.
} 
representativeness bias (Kahneman, Slovic and Tversky, 1982; Arrow, 1982). ${ }^{7}$ Camerer concludes that "a program of empirical work ... could establish what kinds of nonrationality seem to persist under the incentives and leaming opportunities present in natural markets. Such data might lead to economic theory that uses evidence of systematic nonrationality to make better predictions." We accept this challenge and ask: what decision-making biases remain in operating financial markets, where payoffs are significant, poaching is frequently possible, information is extensive and material, and most players participate repeatedly? Section 1.1 briefly reviews the status of the efficient markets paradigm. In section 1.2, we consider a typology of markets that sheds light on the conditions under which the model of efficient markets may have to give way to behavioral explanations. In section 1.3, we discuss four behavioral hypotheses, which are subsequently used to explain a range of selected financial market flows.

\subsection{The efficient markets paradigm}

Financial economists assess the efficiency of a market in terms of its ability to incorporate relevant information, rather than to minimize transactions costs or to attain social welfare desiderata such as Pareto efficiency. More exactly, a market is said to be efficient with respect to an information set if no participant with access to that information can make systematic excess returns. Note that this definition does not require that prices be a sufficient statistic for the information. For example, individuals may need to spend resources to avail themselves of the information 8 impounded in prices in order to form optimal portfolios, even if information acquisition costs can not be justified by the likelihood of discovering mispriced assets. ${ }^{9}$

An efficient market implies that there should be no arbitrage opportunities; that it, it should not be possible to make a sure profit with a zero-risk zero-investment strategy. This seemingly trifling condition led to interesting and empirically successful pricing relations for

\footnotetext{
${ }^{7}$ The representativeness beuristic assigns probubility on the hasis of similarity, ignoring relevant information such as hase rates (prior unconditional prohabilities) and sample sizes.

'If individuals can leam others' information by observing prices, that information will have a public goods aspect: too little of it will be privately provided. If securities may be mispriced, on the other hand, there is a competitive advantage in securing information not possessed by others: too much expenditures on information may be a consequence (Hirshleifer, 1971).

9While simple models of financial market equilibrium generate a universal optimal portfolio (the "market" portfolio in the context of the Capital Asset Pricing Model, for instance), recent models that accommodate differences between individual investors in the breadth of knowledge about assets imply optimal portfolios that must be individually tailored - Merton (1987a).
} 
derivative securities such as options and collateralized mortgage obligations, for which arbitrage strategies entail complex dynamic trading. The celebrated Black-Scholes option pricing formula spawned a large derivative asset-pricing industry, within which the lines between academia and practice have blurred. No-arbitrage conditions pin down relative prices (e.g., how the price of a call option on IBM shares should be linked to the share price). Whether the price level of the share itself is correct is more difficult to establish, since a model of equilibrium pricing must be invoked. Black (1986) - a pioneer of the efficient markets model - observes that the empirical tests to date may not reject the market efficiency hypothesis even if the price levels are off by a factor of $100 \%$.

Of course, as Fama (1990) notes, "The market efficiency hypothesis is an extreme null hypothesis, a point on a continuum, and so almost surely false. The interesting task is ... to measure the extent to which behavior of returns departs from its predictions." After nearly four decades of intensive empirical investigation of investment market prices, the gross evidence generally supports the hypothesis - see recent surveys in Merton (1987b) and Fama (1990). The evidence from firm behavior and the market for corporate control is more controversial: witness the raging debates about whether junk bonds or hostile acquisitions promote efficiency, and whether associated transaction prices are ex-ante appropriate. We know that some cities fail to discount for time in choosing capital projects. And there are myriad stories of firms making uncritical and incorrect use of weighted average cost-of-capital figures in their capital budgeting.

The power of the market efficiency principle provoked ingenious efforts to explain anomalies. These efforts yielded insights in agency theory, asymmetric information equilibria, signaling, and game theory. Clearly, the field gained by maintaining an intuitively wise organizing principle as a null hypothesis. Compare the similar success of the genetic-fitness paradigm for evolutionary modeling, which spawned a vast literature on evolutionary psychology (with ripple effects in philosophy and sociology). ${ }^{10}$

After the early battles in academia, the efficiency benchmark has become a valuable null hypothesis for organizing lessons and studies about financial behavior. Models that purport to violate this principle have to be explicitly articulated and subjected to rigorous testing. Unfortunately, many studies placed such a large prior probability on the market efficiency hypothesis that falsifying findings were almost precluded. For example, the academic consensus about exchange rates is that they are uncorrelated and unpredictable. Nevertheless sophisticated speculators and technical advisors claim to consistently observe and take

\footnotetext{
${ }^{10}$ See Dawkins (1976) on the genetic fitness principle, which shares overtones with the rational selfishness principle in nenclassical economics and methodological individualism in sociology. Dupré (1987) has edited a more recent collection of related essays.
} 
advantage of subtle nonlinear patterns - see Goodman (1982), Engel and Hamilton (1990), and Bilson (1990). Finally, the problem of joint hypothesis testing has led to some tests that have very low power to reject plausible deviations from market efficiency. A priori faith in the power of no-arbitrage has probably clouded the common sense recognition that human errors might persist or even compound rather than cancel each other.

Nonetheless the efficient markets hypothesis provides a natural benchmark, and thus financial markets are a promising arena in which to investigate deviations from rational behavior. The research is facilitated by the facts that financial markets are liquid, and individual motivations are relatively straightforward, in accord with wealth-maximizing hypotheses (possibly modified by risk aversion). Moreover, the operation of these markets is thoroughly recorded, with rich price and volume data readily available.

\subsection{Typology of markets}

The nonrational behaviors of individuals, although well documented, may not be apparent at the market level because many financial markets offer poaching potential (that is, players can take advantage of poor decisions made by others). More generally, aggregate social outcomes reflect both prevailing levels of individual rationality and opportunities for poaching, as table 1 shows schematically. Poachability will play an important role in determining which macro outcomes we study to draw inferences about levels of individual rationality.

Table 1. Models for Outcomes of Social Interactions: Poachability and Rationality

Poachability/Arbitrage Potential

\begin{tabular}{|l|l|l|}
\hline $\begin{array}{l}\text { Individual } \\
\text { Rationality }\end{array}$ & \multicolumn{1}{|c|}{ High } & \multicolumn{1}{|c|}{ Low } \\
\hline Substantial/Full & I. Efficient markets. & $\begin{array}{l}\text { II. Deviations due to sluggish } \\
\text { information flow (e.g., } \\
\text { mispriced open-end mutual } \\
\text { funds). }\end{array}$ \\
\hline $\begin{array}{l}\text { Bounded/Low } \\
\text { (behavioral } \\
\text { anomalies observed) }\end{array}$ & $\begin{array}{l}\text { III. Continual movement } \\
\text { to restore efficiency (see } \\
\text { Table 2). }\end{array}$ & $\begin{array}{l}\text { IV. Gross behavioral } \\
\text { outcomes (e.g., marriages }- \\
\text { poor fits frequent; bargains } \\
\text { - beneficial deals not struck; } \\
\text { finance - inadequate } \\
\text { personal savings). }\end{array}$ \\
\hline
\end{tabular}


When individuals are rational and there are many opportunities for arbitrage, we expect the efficient markets paradigm to be dominant (cell I in Table 1). At the other extreme (cell IV) behavioral models should provide a better description of aggregate outcomes. For example, because of long lead times, poor institutional planning, and individual failures of foresight, we observe cycles of excess- and under-production of teachers. The situation is akin to the corn-hog cycle familiar to economists, with the crucial difference that in the agricultural arena, futures markets facilitate an efficient smoothing of suboptimal swings. Many of the least happy areas of human activity fall into cell IV. The mischosen marriage partner or poorly fitting job is prototypical. So too are patterns of preferences-such as excessive attention to one's relative as to opposed to one's absolute position-that are inconsistent with what we normally assume for rationality. For example, the inadequate levels of personal savings in the United States may be due to excessive competition in consumption levels, as a means to signal one's status (Frank, 1985).

Cell IV is also the sad domain where many an advantageous exchange is not made, perhaps because of greed or desire to do better than the other party, or merely because of the intractability of bargaining. One of the undersung virtues of the market is that by putting many participants on each side of bargaining situations, it defines the way the surplus from striking a deal should be divided, and thereby avoids costly impasses. Thus market outcomes establish a price for carrots; as buyers we accept it when it is below our reservation price, or else move on to the rutabaga stand, without wasting our time trying to cajole the carrot seller into lowering his price.

It is in cells II and III that a merger of behavioral considerations and economic market analysis can be most fruitful. In situations that are characterized by low poachability but in which rational choice conditions predominate (cell II), we expect economic paradigms to succeed, albeit with behavioral residues leading to periodic observable anomalies (see section 2). For example, if most drivers are rational, we would expect them to choose the most economical route for commuting. This assumption is fruitfully invoked in transport models even though rational commuter $A$ can not derive any advantage for herself from (poach upon) misguided B whose "shortcut" adds 10 minutes to his trip. Even if individuals are fully rational, they may not possess all relevant information, and those with superior information may not be able to capitalize upon it. Thus, open-end mutual funds can sell at inappropriate prices, and firms with market power may produce inappropriate products. Rationality, by itself, provides little guidance as to what outcomes are appropriate. If it did, the participants would immediately gravitate to such outcomes.

The expected patterns for situations corresponding to cell III depend crucially on the dynamics of the situation and the magnitude of flows that nonrational participants bring to the 
market." (See table 2.) If, as we suspect, many financial market participants are less than perfectly rational, their actions will be well camouflaged in aggregate statistics by the poaching activities of better-informed, more rational, and ultimately richer participants.

Cell III is of particular interest for financial markets. Processes of natural selection underlie its operation. If rational poachers are large relative to the market, they will quickly restore rational aggregate outcomes. Thus, for example, it is widely accepted that one can not make money speculating on major New York Stock Exchange securities on the basis of publicly available information. Indeed, this very feature-the appropriateness of pricesprotects small, possibly nonrational investors whose stock purchases may be guided by astrology, a worthless technical system, or mere whim. (They lose something nevertheless: the transactions costs of buying and selling.)

Table 2. Detailing Cell III: Small, Low-Rationality Participants in Markets with Poaching

\begin{tabular}{|l|l|l|}
\cline { 2 - 3 } \multicolumn{1}{c|}{} & \multicolumn{1}{c|}{ Inflows of small, low-rationality participants } \\
\hline Scale of Poaching & \multicolumn{1}{c|}{ Low } & \multicolumn{1}{c|}{ High } \\
\hline $\begin{array}{l}\text { Large relative to } \\
\text { market size }\end{array}$ & $\begin{array}{l}\text { Efficiency in observations } \\
\text { (stock prices on NYSE). }\end{array}$ & $\begin{array}{l}\text { Strong progress toward } \\
\text { rational outcomes, though } \\
\text { not without dangers for } \\
\text { poachers (Japanese stock } \\
\text { market). }\end{array}$ \\
\hline $\begin{array}{l}\text { Small relative to } \\
\text { market size }\end{array}$ & $\begin{array}{l}\text { Natural selection over time } \\
\text { (evolution of options market } \\
\text { from 1960s to the 1980s). }\end{array}$ & $\begin{array}{l}\text { Sustained periods of } \\
\text { inefficiency (oil markets, } \\
\text { gold markets). }\end{array}$ \\
\hline
\end{tabular}

If a sustained flow of resources from nonrational investors is large enough, it may push a market away from a rational equilibrium for long periods of time. Indeed, nonrational investor psychology may defeat the efforts of rational poachers, who generally work on borrowed money and high leverage; they can not wait forever for markets to come to rational/fundamental equilibrium. ${ }^{12}$ The short-term speculator who knows long-term

\footnotetext{
"Bounded rationality is substantially different from full rationality with regard to informalion acquisilion and processing costs - see Simm (1957) for discussion of procedural rationality (consistent with bounded rational behavior) versus suhstanlive rationality.

${ }^{12}$ Consider an invessor who, in the mid-1980s, correclly realized that that a P/E ralio of 40 for Jananese oquities was unsustainably high. By acling on this belief (i.e., shorting the Japanese equity markel) the investor would have kost money every year from 1985 w 1989 . Finally in 1990, if slill able and willing (o) persist in his faith, he
} 
equilibrium values wants to have a reasonable number of naive speculators in the market, but not an excess.

When poachers are small relative to the market, they may be able to profit for sustained periods of time; eventually their prosperity will change the balance and the push toward rational aggregate outcomes will accelerate. In the 1960s and early 1970s, before option pricing formulas became widely known and accepted, it was relatively easy for mathematically oriented traders to make profits on American options exchanges. ${ }^{13}$

If poachers are small and new nonrational market participants flow in continuously, there may be sustained periods of inefficiency. In certain markets, moreover, even dispassionate experts may have little guidance as to appropriate prices. Examples include the market for gold, which is driven predominantly by speculative expectations rather than by fundamental forces of demand in use, or the market for oil, whose performance depends on a quirky oligopoly and idiosyncratic international events (witness the price gyrations during Kuwait's takeover by Iraq and the subsequent Gulf War). Many commodity futures markets may also fall into this category.

Not all financial markets offer equal poaching potential. Open-end mutual funds, for example, cannot be sold short. Portfolio balances (observed as flows) and adjustments are also not directly poachable. We provide some selective evidence in the next section on such funds and flows. Moreover, as Thaler and Ziemba (1988) show, poaching does not necessarily eliminate irrational pricing even in places where we might expect it to do so: the markets for place and show bets at racetracks are inefficient (in the sense of offering opportunities for profit), despite the presence of many willing arbitrageurs. ${ }^{14}$ Similarly, Lee et al. (1991) report behaviorally driven premiums and discounts for closed-end mutual funds, which are traded on stock exchanges like common stocks, and are poachable. ${ }^{\text {is }}$

would have been rewarded by catching the roughly $40 \%$ fall in the Tokyo Stock Exchange that brought its $P / E$ ratio down from over 50 to 30 (which is still exceedingly high by U.S. standards).

${ }^{13}$ By the 1980s the game had hecome much harder. Machines available on exchanges printed out "scientificully determined" values for options. In addition, dozens of professional bridge players. whose principal skill may be rapid rational decision under short-term uncertainty. floxded the exchanges and diminished the returns to other floor traders and poachers.

${ }^{14} \mathrm{Also}$, the favorite-kongshot bias leaves a positive expected value for racetrack thetting on odds of 3-10 or below.

${ }^{15}$ A strategy of investing in closed-end funds that trade at deep discounts (20\% or greater) relative to net asset value generates positive excess returns. 


\subsection{Behavioral Hypotheses}

Financial markets can be viewed as an ecosystem, populated by rational and nonrational investors. Depending on their relative numbers, and the ability of the first group to capitalize on the errors of the second, equilibria with varying qualitative features will arise. Generations of economists have refined a well-specified theory of the way rational participants will behave. Nonrational participants, however, come in many different species.

Behavioral hypotheses can be introduced into the study of financial markets in a range of ways. For example, one might pose explicit behavioral hypotheses about individual activities and then invoke the usual economic method for aggregation and market clearing - as Shefrin and Statman (1989) do in developing a prospect-theoretic model of capital asset pricing. Or one might conjecture that outcomes arise as if from a single representative agent endowed with nonrational charocteristics. The latter approach provides a suitable framework for preliminary investigation to predict patterns substantially different from the rational choice paradigm.

We discuss four behavioral hypotheses, variants of which are found within the mainstream psychological literature, for explaining some aggregate features of financial markets: ${ }^{16}$

1. Barn door closing. Bam door closing, in the horse protection sense, refers to undertaking behavior today that would have been profitable yesterday. Investors seek to reproduce actual or imagined past investment successes by investing today in the same way. (When the current strategy is to continue an actual past strategy, it is often called "riding the winners.") In efficient markets, by contrast, prevailing asset prices capture all rational expectations about future prospects; it is impossible to identify profitable strategies. If this behavioral trait is significant, investors might be slow to re-enter the stock market after a plunge (e.g., the $1987 \mathrm{crash}^{17}$ ), and foreign investors might withhold investment flows to the United States after periods in which the dollar depreciated rapidly.

\footnotetext{
${ }^{16}$ Of course, transactions costs and impediments (1) arhitrage (essentially nonbehavioral explanations) may be sufficient to cause deviations from financial market efficiency. For example, if institutions are prohibited from trading or offering securities overseas, then cross-border assets may not be tightly related to each other - see Gultekin et al. (1989) and references therein.

Our hypotheses are illustrative. Many other hehavioral tendencies identified in laboratory situations should be tested in the cxuldron of financial markets, where the stakes are big and most players are long-term participants.

${ }^{17}$ In early 1990, NYSE telephone surveys found investors less likely to invest in stocks than they had been three years earlier, with investors specifically citing the 1987 crash as a key reason (Market Volatility and Investor Confidence, Report to the Bourd of Directors of the New York Stock Exchange, lnc., 1990).
} 
2. Expert and Reliance Effects. An expert effect (i.e., overemphasizing the field you understand best; Heath and Tversky, 1990) could explain the lack of international diversification even by professionals who specialize in asset classes.

Complementing the expert effect in financial markets is a reliance effect: decision makers often rely on the advice of individuals with expert knowledge, even though using the expert is costly and there is no proof that such reliance will produce better outcomes. Thus, despite meager evidence that experts can outperform the stock market, investors hesitate to rely on their own judgment in selecting a portfolio. Instead they pay experts handsomely for managing their funds. The extraordinary success of the mutual fund industry illustrates the reliance phenomenon at work. Despite a modest overall performance record, consistent with efficient markets ${ }^{18}$, the mutual fund industry has grown spectacularly since the early 1970s; by 1988, there were more mutual funds (over 2700 ) than there were stocks on the NYSE.

3. Status Quo Bias. Investors tend to stick with strategies because of a reluctance to depart from the status quo, a widely observed human tendency (Samuelson and Zeckhauser, 1988). Status quo bias may be promoted by reliance on rules of thumb, which is an outgrowth of bounded rationality. Reinforced by expert effects, status quo bias may deter individuals from investing in areas beyond their expertise. Most U.S. investors, for example, are reluctant to hold significant positions in non-U.S. securities despite prospective gains in diversification. Status quo bias is also stimulated by concerns about regret, which tend to make errors of omission (failing to sell a stock that later goes down) much less serious than errors of commission (selling a stock only to see it perform spectacularly). ${ }^{19}$ A period of learning how to function in changing financial markets - a pattern not acknowledged in conventional finance theory - could also explain status quo bias. ${ }^{20}$

4. Illusions, Framing, and Data Packaging. Since U.S. investors deal mainly in dollar transactions, they may not pay enough attention to exchange rate fluctuations and their implied

\footnotetext{
${ }^{18}$ Over the past five years, only 45 or so of the 1100 funds folkwed by Schabacker Investment Management have bettered the S\&P 500's annualized return.

${ }^{19}$ Status quo bias would be rationally reinforced by transactions costs incurred in getting out of a position (brokerage fees, exit charges, and taxes).

${ }^{20}$ Most United States investors, for example, may not know how to go about investing in Japan, though that market is now open. Indeed, the economic costs of investing directly on the Tokyo exchange are small. Thus if the Japanese stoxks that issue ADRs in the Uniled States, or the U.S. stucks that are traded on the Tokyo Exchunge, turn out to have much higher levels of cross ownership. that might he considered evidence for a learning factor contributing (o status quo bias. However, the causality may run the other way: ADRs may be made available specifically for those stocks that are desired by foreign investors.
} 
consequences; this would be a framing error. ${ }^{21}$ Similarly, investors with international holdings may not fully understand the consequences of exchange rates. When the franc doubles against the dollar, the rational investor should double the amount of incremental dollar-flows directed to franc-denominated assets, but this requires an appreciation of exchange-rate effects on optimum portfolio weights. Another variant of exchange-rate illusion arises when investors conclude that certain currencies are weak or strong, beyond what is implied by interest rate parity or exchange rate futures prices. Finally, the framing of data in the media (datapackaging) will affect the relations between ultimate variables (flows and prices) and their proximate causes.

\section{Observed Behavioral Traits in Financial Markets}

This section reports on empirical evidence in favor of the behavioral hypotheses outlined above. We focus first on incremental flows to open-end mutual funds. (It is fortunate for the mutual fund industry that, despite the efficient markets paradigm, the typical individual investor believes winners can be identified on the basis of some combination of marketing materials, investment philosophies, and evidence on past performance.) We also discuss investment flows, both to U.S. equities and across national borders.

\subsection{Holdings in and flows to mutual funds}

If financial markets price assets efficiently, why do many individuals invest through professionally managed funds even though they must pay fees, and uncontrollably realize capital gains that are subject to tax? Neither average returns nor reduction of risk justifies this strategy. For example, 20 judicious individual-stock purchases would give reasonable diversification. ${ }^{22}$ We made a rough calculation of the returns to four buy-and-hold strategies over the 13-year period 1975-1987, involving funds and individual securities (table 3). One strategy (a) is to randomly select a no-load growth fund from a sample of 96 such funds. ${ }^{23}$ Three alternative homemade buy-and-hold strategies were considered by taking equally

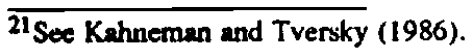

22 Popular publications such as Money or Eortes rarely point out how easily one can diversify. Most financial publications carry detailed rankings of mutual fund performance, but virtually no comparixins with stock portfolios chosen al random. Fabled money manager Peter Lynch. in his recent bouk One Up On Wall Street (1989), has suggested thal individuals should purchase individual stocks on the basis of personal expertise, say about the company's products. Though perhaps working against diversification, such a stralegy might give investors sufficienl confidence to invest for themselves.

${ }^{23}$ See Hendricks, Patel, and Zexkhauser (1990) for the exact sample and its adequate representativeness.
} 
weighted positions in 20 stocks randomly selected from the 100 largest NYSE stocks and 100 bottom-decile NYSE stocks. Strategy (b) consists of positions in 10 big and 10 small stocks. Strategy (c) involves only small stocks, while strategy (d) involves only big stocks.

Table 3. Buy-and-Hold Perfonuance:

Mutual Funds versus Hone-made Portfolio

\begin{tabular}{|l|c|c|}
\hline \multicolumn{1}{|c|}{ Strategy } & Mean Returns & $\begin{array}{c}\text { Standard Deviation } \\
\text { of Mean Retums }\end{array}$ \\
\hline (a) No-load growth mutual fund (96 selections) & $16.1 \%$ & $5.1 \%$ \\
\hline $\begin{array}{l}\text { (b) Portfolios of } 10 \text { big stocks \& } 10 \text { small stocks (10 } \\
\text { simulations) }\end{array}$ & $19.6 \%$ & $2.6 \%$ \\
\hline (c) Portfolio of 20 small stocks (5 simulations) & $23.3 \%$ & $3.5 \%$ \\
\hline (d) Portfolio of 20 big stocks (5 simulations) & $14.3 \%$ & $1.6 \%$ \\
\hline
\end{tabular}

In table 3, both strategies containing small stocks ( $b$ and $c$ ) produce a higher mean return than a random mutual fund as well as reduced uncertainty in expected outcome, as the standard deviations suggest. These results support the view that mutual fund ownership offers negligible diversification gains over easy homemade portfolios. Also the active "expert" management of mutual funds evidently led to a wider divergence of overall performance than would have resulted from a passive random allocation of funds among stocks. That individuals rely so heavily on mutual funds - despite the ease of diversification in a personal portfolio, the widespread discussion of efficient markets, and (frequently) personal evidence that their fund has underperformed the market - indicates, in our belief, the importance of the reliance phenomenon.

In the rational framework, the annual flows across funds from year to year are puzzling too. Markowitz (1952, 1959) and Sharpe (1964) address the rational portfolio choice problem and its implications for market pricing and efficient portfolio decisions. Their models imply that the optimal mix of asset holdings should be the same for all individuals, namely proportional to the total market values of the securities. ${ }^{24}$ When combined with the efficient markets hypothesis (Fama, 1970), this view leads to a passive (i.e., nontrading) portfolio strategy. If all investors followed this strategy, observed flows should display no patterns and should be due entirely to liquidity/consumption needs or incremental savings.

${ }^{24}$ The recently introduced multifactor Arbitrage Pricing Theory (APT) is no more successful than the CAPM in explaining investor flows. Morerover, the factors that APT posits to underlie security pricing remain to be identified, though Chen. Roll, and Ross (1986) have made a first cut at this important task. 
We hypothesize, in contrast, that flows to open-end mutual funds may reflect status quo bias, framing, and data-packaging. The strength of status quo bias can be assessed by examining flow persistence over time and the relationship of flows to fund size. Although learning costs may justify a modicum of persistence, the opportunity costs of persistent behavior are often high enough to warrant an investment in self-education. The main cause of persistence seems more likely to lie in such phenomena as regret avoidance - an attempt to avoid a mistaken act of commission, such as selling a fund that goes up subsequently.

The framing/data-packaging conjecture is consistent with psychological evidence that people follow simple rules based on direct evidence available to them. Not surprisingly, mutual fund performance rankings are compiled on a regular and timely basis, and are widely followed. Mutual funds that do relatively well tout their performance prominently in their advertising. Those that don't, search for the measure that puts them in the best possible light. With some caveats, the investment advisory literature advocates investing in top-ranking performers. The data-packaging effect can be studied by comparing the effects on flows of (a) widely reported ranks, and (b) cardinal measures of absolute or risk-adjusted performance, which are preferable from the standpoint of financial theory but may not be easily understood.

Consider table 4, which is based on Patel, Zeckhauser and Hendricks (1991b, tables 2 and 3). 
Table 4. Explaining Anmual Flows to Opes-End No-Load Growth Mutual Funds: 96 funds during 1976-1987

Regression: Flow $=\alpha_{\mathrm{i}}+\beta_{1}$ Flow $_{\mathrm{i}, \mathrm{t}-1}+\beta_{2}$ Size $_{\mathrm{i}, \mathrm{t}-\mathrm{I}}+\beta_{3}$ Return $_{\mathrm{i}, \mathrm{t}-1}\left\{+\beta_{4}\right.$ Rank $\left._{\mathrm{i}, \mathrm{t}-\mathrm{i}}\right\}+\epsilon_{\mathrm{it}}$
\begin{tabular}{|l|c|c|c|c|c|c|}
\hline & $\beta_{1}$ & $\beta_{2}$ & $\beta_{3}$ & $\beta_{4}$ & $\bar{R}^{2}$ & $\hat{\rho}$ \\
\hline Base case & $\begin{array}{c}0.75 \\
(27.07)\end{array}$ & $\begin{array}{c}0.05 \\
(11.05)\end{array}$ & $\begin{array}{c}0.20 \\
(5.10)\end{array}$ & $-\cdots$ & 0.76 & -0.17 \\
\hline Are ranks important? & $\begin{array}{c}0.70 \\
(24.63)\end{array}$ & $\begin{array}{c}0.05 \\
(10.93)\end{array}$ & $\begin{array}{c}-0.18 \\
(-2.13)\end{array}$ & $\begin{array}{c}0.21 \\
(5.43)\end{array}$ & 0.73 & -0.15 \\
\hline
\end{tabular}

Notes: "Size" is the dollar value of the fund. "Flow" is the change in the size of the fund (MMS) after correcting for fluctuating values of the assets in which the fund is invested (but net of dividends declared by the fund in the period). "Return" is the realizable return to an investor who buys the fund at the beginaing of the period and sells it at the end of the period, i.e., total asset return performance of the fund (inclusive of capital gains and dividends) but net of management fees and expenses. "Rank" is an ondinal measure constructed from "Return". The regression is estimated using feasible generalized least squares (GLS), which allows for different error variances between years. Here t-statistics are in parentheses. $\bar{R}^{2}$ is the usual measure of proportion of variance in dependent variable that is explained by the regression after degrees-of-freedom correction. $\dot{\rho}$ is the estimate of the first-onder autocorrelation of the residuals; it is always small and suggests that the regression adequately captures timedependencies.

The results strongly confirm the expected associations. About three-quarters of the crosssectional time-series variation in annual flows (96 funds over 1976-87) can be explained by four main patterns:

1. Status quo bias (persistence): other things equal, a one-dollar flow in the past year implies a 75 cent flow in this period.

2. Status quo bias (size): being one dollar bigger in size at the beginning of the period induces a 5 cent increased flow.

3. Past performance: a return $1 \%$ above the cross-sectional mean return in the previous period implies a $\$ 200,000$ increased flow in this period. (The median fund in the sample held approximately $\$ 80$ million in assets and grew by $\$ 5$ million per period.)

4. Effects of data packaging: rank measures, which are widely reported, appear to be more relevant in explaining flow patterns than quantitative performance measures.

Why might investors rely on past performance? Perhaps, following Tversky and Kahneman (1971), investors expect the properties of large samples, such as convergence of relative frequency to population parameters, to hold in small samples too: that is, they tend to generalize too readily from small samples, or incorrectly infer autocorrelated performance from observed runs in mutual fund returns that actually arise from random walk processes. A more straightforward justification follows from the results of Hendricks, Patel, and Zeckhauser 
(1990), who report significant excess returns of 1-2\% per quarter from selecting the open-end mutual fund that performed best in the previous quarter. (This result, in itself, is inconsistent with the efficient market hypothesis). ${ }^{2 s}$

Aggregate flows from the household sector to mutual funds also have behavioral features. If the barn-door-closing hypothesis is germane, individuals will buy more mutual funds after the stock market goes up, and sell after it plunges. Further, if there is some behavioral threshold effect, this reaction will manifest itself mainly for large changes. Consider the fraction, $f$, of the U.S. household sector's flow of financial purchases (composed of direct and intermediated net purchases of equities, bonds, and short-maturity or demand deposits) directed to mutual funds. Quarterly data on $f$ are constructed from the Federal Flow of Funds for the 1952Q1-1990Q1 period and exclude households' indirect claims, such as pensions.

Table 5 reports on a regression of $f$ on four of its own lags, returns on the equity market (as proxied by the value-weighted NYSE index), and changes in yields from investing in Treasury bills.

\footnotetext{
${ }^{25}$ These results, however, do not restore a rational explanation for the flows' dependence on past performance ranks, since the optimal strategy is to select only the top performers and shift investments away from all other funds. Also, the observed persistence in flows to funds is now identified with opportunity costs of failing to switch. Further, since predictable underperfomers do attract substantial funds, there are evidently some overpriced managers in the finuncial marketplace, and some less than fully rational mutual-fund buyers are not protected by overall market efficiency. In sum. although there are rational grounds to justify active management of fund purchases, the actual aggregate behavior is, at hest, rational in limited aspects.
} 


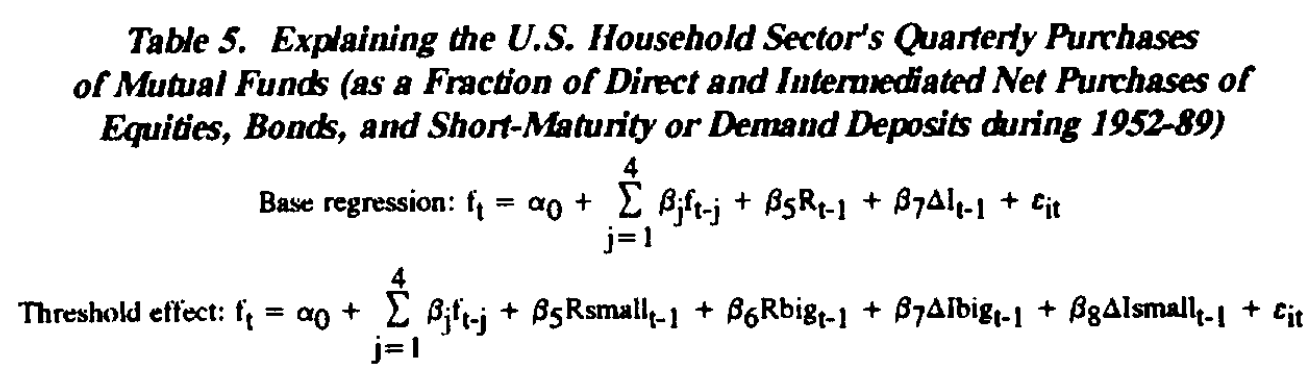

Estimates of statistically significant coxefficients or coefficients of interest:

\begin{tabular}{|c|c|c|c|c|c|}
\hline & $\beta_{1}$ & $\beta_{4}$ & $\beta_{5}$ & $\beta_{6}$ & $\overline{\mathrm{R}}^{2}$ \\
\hline Base regression & $\begin{array}{c}0.49 \\
(6.15)\end{array}$ & $\begin{array}{c}0.15 \\
(1.8)\end{array}$ & $\begin{array}{c}0.26 \\
(3.55)\end{array}$ & - & 0.44 \\
\hline Threshold effect & $\begin{array}{c}0.47 \\
(5.83)\end{array}$ & $\begin{array}{c}0.14 \\
(1.94)\end{array}$ & $\begin{array}{c}0.06 \\
(0.47)\end{array}$ & $\begin{array}{c}0.35 \\
(4.09)\end{array}$ & 0.45 \\
\hline
\end{tabular}

Notes: " $R$ " is the retum on the equity market (as proxied by the value-weighted NYSE index). "Rbig" ("Rsmall") includes only equity retums that are greater (smaller) than $10 \%$ in absolute value, and is zero otherwise.

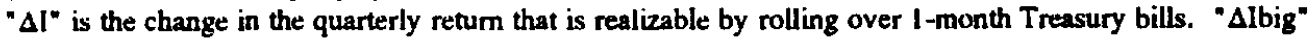
(" $\Delta$ lsmall") includes only changes in $\Delta I$ that are greater (smaller) than $0.25 \%$ in absolute value, and is zero otherwise.

Here $t$-statistics are in parentheses. $\bar{R}^{2}$ is the usual measure of proportion of variance in dependent variable that is explained by the regression after degrees-of-freedom correction. The second regression, with decomposed returns, finds that only large returns have significant effects on net household flow purchases of mutual funds. Tests for autocorrelated errors, not reported, do not indicate any misspecification of the estimated regression.

In the first row of the table, we observe an economically large and statistically significant positive coefficient, $\beta_{5}$ in the base regression, on equity returns, which is consistent with bam door closing. (Simultaneity problems are avoided since most mutual funds are open end, and hence their supply of shares is highly elastic.) When the market has done well, one wishes that one had invested there, rather than purchase short-term assets (which normally represent more than $50 \%$ of the households' flows) and fixed-interest assets (which represent about $21 \%$ ), and vice-versa. After the fact, one makes such investments. The second row of Table 5 reports on a regression that decomposes quarterly equity returns into large $(>|10 \%|)$ and small changes. We observe a threshold effect: only large changes matter, a further indication of nonrational or bounded rational behavior. ${ }^{26}$

\footnotetext{
${ }^{26}$ Spexifically, $21 \%$ change in equity retums beyond a threshold change of $10 \%$ induces a $6 \%$ change in the rate of investment in mutual funds hy housebolds. (The results are not restricted to a particular suhperiod; of the 25 large-change observations, 10 are from the 1950s and 1960s, and 15 are from the 1970s and 1980s.)
} 


\subsection{Net Flows into Equities and Transnational flows}

These behavioral approaches can be extended to explain the flows of net new issues of equities as a percentage of GNP. We conjecture that the issuance of equities is at least partly driven by nonrational traits of participants. Again, we posit status quo biases and expert and reliance effects on the market. (Firm managers rely on investment bankers who try to issue equities when market conditions are "good," though with efficient markets this is an impossibility.)

Empirical studies of security flows have typically assumed rational behavior on the part of all market participants. Studies of the supply and demand for long-term bonds (Friedman, 1977 and 1979) have posited structural equations that are linear in expected returns and homogeneous in wealth. Such a specification implies, however, a separation of the investment-consumption decision and the portfolio allocation decision. This assumption is implausible with regard to the supply of financial assets, since casual observation suggests the presence of boom-and-bust cycles in corporate security issuance.

We examine the evidence on the net flow of funds to equity markets (new issues less repurchases in constant dollars) by the non financial corporate sector of the United States during the period 1953-1984. Our particular concern is whether firms that issue equities seek to identify times when they can realize a relatively high price for new stock, implying that they reject the efficient markets hypothesis.

Consider the regression of net equity flows on (i) lagged equity flow; and level of and most recent change in (ii) dividend yield based on the Standard and Poor's 500 portfolio (inversely related to cost of the issue for pre-issue shareholders), (iii) vector of interest rates (proxy for cost of bond substitute), (iv) internal cash flows (readily available alternative), and (v) capital expenditures (proxy for need for funds). The well-fitting regression (numerical estimates not shown) explains $60 \%$ of the time-series variation in net equity flow's. The significant marginal relations are the following: a positive partial correlation with own lag; a negative partial correlation with own cost; and a negative partial correlation with cost of bond substitutes. The latter two relations are consistent with attempts by firms to issue equity when market conditions are favorable.

An efficient-markets explanation for the correlation between market conditions and new equity flows can be proposed: the flow of prospective positive net-present-value projects increases in periods when security market conditions are good, which induces an increase in security issues to raise needed funds to invest in such periods. Assuming that the capital expenditure in the regression equation is not an adequate proxy for projects' needs, the net effect is to generate the observed marginal correlations. However the case for the simpler behavioral explanation - that issuers believe they can identify windows of opportunity (in violation of the efficient markets hypothesis) - is reinforced by corroborating evidence from 
other markets. Kim and Stulz (1988) document bond issue timing between domestic and Eurobond markets; Lee, Shleifer, and Thaler (1991) document timing of closed-end fund issues; and Ritter (1991) documents timing of initial public offerings of equity.

We have explored a supply-side phenomenon in the flow of funds. What can we learn about demanders? In particular, how do overseas investors choose their levels of investment in U.S. securities? For example, many commentators have attributed the much-remarked jump in Japanese purchases circa 1984 to the relaxation of Japanese government rules limiting foreign purchases by Japanese institutions. In this case a known policy change has led us to look for its effects within financial markets, a form of availability bias.

Unfortunately, this Japan-oriented theory is undermined by data on other international investors. Figure 1, for example, contrasts U.S. security purchases from the United Kingdom and Canada with those of Japan. British and Canadian investors began to boost their U.S. holdings at the same time as Japanese investors. We observe that theories and explanations are themselves subject to an availability hypothesis. ${ }^{27}$ It appears that some more general phenomenon relating to the U.S. market itself is required for a robust explanation of these transnational flows.

\section{Fields for Exploration}

Looking predominantly at flows of funds, a relatively unexplored area, we have documented nonrational behavior in financial markets. A fleet of additional behavioral anomalies have been identified in the psychology literature. Do they too appear in financial markets? A systematic investigation of this question could proceed in three directions: (1) assessment of behavior in financial markets, seeking evidence of anomalies documented in other realms; (2) empirical testing of models of nonrational behavior; and (3) attempts to explain observed phenomena that seem inconsistent with rational behavior assumptions, and shed light on nonrational behaviors. The first path has been illustrated in the previous sections. The second and third are considered below in our discussions of herd behavior and the survival of financial markets respectively.

\subsection{Herd Behavior: Model and evidence from debt-equity ratios}

In addition to the four behavioral traits discussed earlier, we posit that flows in financial markets are influenced by herd behavior - a tendency to incline actions to some group norm. Such clustering of behavior is well known in clothes fashions or recreational activity, such as

\footnotetext{
${ }^{27}$ The availability heuristic assesses probability by recalling similar occurrences from one $s$ available store of memories, which leads to hiases related to retrievahility of instances and imaginability.
} 
newly popular mountain biking. There would seem, however, to be little justification for clustering fads in financial markets. Presumably, each decision-maker is choosing for himself, and there is no explicit cost associated with being away from others. But we shall argue, first theoretically and then with suggestive empirical evidence, that commonality in actions is significant.

At least three different effects tend to produce herding behavior:

(a) Free-riding in information acquisition. Some individuals, by luck or skill or effort, will obtain superior information on which they can act. Less advantaged individuals will mimic the actions of others who they believe are better informed. Recent models in this vein include those of Hendricks and Kovenock (1989) and Scharfstein and Stein (1990).

(b) Protection from being close to the group. The agency paradigm emphasizes that agents (e.g., managers acting on behalf of shareholders) often know more about their own tastes, abilities, and actions than the principal does. Under such conditions of asymmetric information, it may be efficient to make payoffs to agents that are based on their relative performances. In such a scenario, agents may find it advantageous to herd, particularly if they are risk averse. ${ }^{28}$

(c) Fundamental preference-level concern with group norms. For example, if outcomes are poor, the costs of self-reproach may be greater if one has "stepped out" on one's own, away from the group.

These factors may have nonrational underpinnings. We suspect that in many situations individuals overestimate the information possessed by others, not recognizing the covariance of all players' ignorance. (A good recent example was provided by investors in Rhode Island who maintained large accounts in local banks, which faced serious prospects of nonperforming assets and were backed by an insurance agency of dubious means, simply because nobody else withdrew their funds. They jointly realized painful outcomes when deposits were frozen at the beginning of 1991.)

Consider a decision maker who is concerned about how his action affects his self-image, or the ways others perceive and will reward him. An additional component of utility, well established in the behavioral literature, captures a concem about matters such as regret. Regret in the traditional literature derives from choosing an action that is revealed to be

\footnotetext{
${ }^{28}$ Beyond risk and retum, individuais responsible for university endowments, be they portfolio managers or bxards of trustees, are likely to consider how they perform relative to competitor endowments. Portfolios are likely to the tiltod toward some common allocation and away from the efficiency frontier. Stanford's endowment managers may thus worry about their holdings relative to Harvard's, and vice versa (Jack Meyer, President, Harvard Management Company, personal conversation, 3/12/91). Leading American universities, for example, appear to underinvest in foreign equities as a group. Many individual managers may recognize this missed opportunity but may be hesistant to step out of line.
} 
inferior given the state of the world that later turns out to prevail. Our hypothesis is that a more complex measure of regret is needed, because the actor cares about the choices of other players confronted with roughly the same decision problem. For any given loss, regret is tempered when others have made a greater mistake ex post, and augmented when one would have done better by acting more like others: one sees oneself as less blameworthy for a poor outcome if one has taken roughly the same action that others took in equivalent circumstances. Attending to such concem will draw together the actions of individuals who are commonly situated. Thus we should expect to see herding when players have preference functions with other-regarding regret. Herding would also be expected in situations where falling below an external norm, say on how hard a professor should work, imposes severe losses in self-regard or external attitudes.

A prospect theory (Kahneman and Tversky, 1979) like phenomenon may apply as well, with further implications for herding. Rising above the norm gains less than is lost by an equal deviation below, and further rises offer diminishing benefit. Where adherence to the norm is likely to be a binding constraint on many participants, we should expect to see many players very close to the norm, not seeking to rise above it. Moreover, falling below the reference point - in this case the group norm - imposes a diminishing marginal cost, and those who do fall below might do so significantly.

If actions are uncoordinated, particularly if players' situations differ, the group norm will be fuzzy. In such circumstances the group norm will exert less pull, and individual behavior will be less responsive to social factors. Other things being equal, herding behavior should be less common in situations where group norms are ill-defined or nonexistent.

For illustrative evidence on herd behavior in financial markets, consider the annual ratios of debt (book value) to equity (market value) for the 200 largest U.S. firms (by sales) during the period 1971-89. Presumably, this choice of the debt-to-equity ratio represents a careful weighing of the prospects of higher returns from leverage against the desire to be prudent. ${ }^{29}$ On the COMPUSTAT database, 15 of these firms had some missing observations, and three clearly had outlier debt/equity ratios (in excess of five); this left us with a usable sample of 182 firms. We assigned firms to 10 industries based on a classification by two-digit SIC codes.

We investigated the herd migration explanation by regressing the firm's debt-equity ratio on two own lags and one lag of the industry ratio. (The expected industry ratio is proxied by

\footnotetext{
${ }^{29}$ The literature on the determinants of capital structure choice has mushroomed in the last decade, with recent models drawing on agency theory. asymmetries in information, corporate control contests, and so on. See Harris and Raviv (1991) for an excellent survey. We do not control for the competing explanations in our exploratory investigation.
} 
its lagged value; its contemporancous value may exhibit a positive relation simply because of common shocks that influence the market value of equity across firms in an industry.)

A herd migration tendency for a firm is indicated by a significant positive sign, a tstatistic $>2$, on the industry ratio. Figure 2 summarizes the distribution of the t-statistics of firms grouped by industry in the form of box-plots. The heavy horizontal line at the center of each box-plot represents the median of the distribution; the box includes the central $50 \%$ of the distribution. ${ }^{30}$ We observe that the coefficients are positive and several are significant (tstatistic above 2.0), more than half for food and tobacco, paper, and oil and gas. ${ }^{31}$ The median t-statistic is never significantly below 1.0; moreover six out of ten industry medians are not significantly below 2.0 .

The evidence suggests that corporate executives determining debt/equity ratios are strongly influenced by the choices of their peers within the industry. Three reasons may be posited: (1) decision makers gain information from what similar firms are doing; (2) they secure protection from criticism (including self-criticism); (3) participants on the other side of the market (such as lending institutions or the buyers of new issues) are engaging in herd behavior, thereby inducing observed clustering among participants on this side.

\subsection{Survival of Financial Markets}

Future investigations should also proceed in the opposite direction, starting with puzzling phenomena within financial markets and attempting to identify the types of behaviors that could produce them. Consider futures markets, in which speculators account for the overwhelming volume of business. For almost thirty years it has been recognized, as the Wall Street Journal recently underscored in a recent special supplement on futures markets, that the typical small speculator loses more than $20 \%$ of his stake annually. What induces small speculators to participate despite such unfavorable odds? An ecological metaphor asks what will enable such markets to survive, since they are expensive to operate, and their outcomes are highly unfavorable to many participants, who have the option of placing their monies back in stocks and bonds (Zeckhauser and Niederhoffer, 1983). The survival puzzle goes deeper:

\footnotetext{
30 The vertical lines extending heyond the hox are drawn to the outermost values up to the median $\pm 1.5 \times$ boxheight. Each outlier treyond (only paper in our sample) is indicated by a circle.

${ }^{31}$ The angled sides of the box (notches) enable comparison of medians: informally, the medians are different if the angled sides do not overlap.
} 
not only must small speculators systematically lose money; their resources and/or their ranks must continually be replenished. ${ }^{32}$

We conjecture that financial markets must offer prospective expected losers the ability to convince themselves that they could (should) have made the right choices had they tried harder, or that they will be able to do so in advance in the future. An appropriate metaphor is the widespread American activity of Monday morning quarterbacking: fans of professional football believe by Monday (with the unacknowledged benefit of hindsight) that they would have been better able than their team to identify the strategy that would have won the Sunday game. To confirm the general pervasiveness of Monday morning quarterbacking, the reader should ask finance-oriented friends whether they realized that the stock market was overpriced in October 1987, shortly before the worldwide crash.

Individuals who can delude themselves into thinking they could have made money given past market behavior, may then act on that delusion by trading securities in contexts where they will now be losers on average. In retrospect, such individuals can rationalize past losses by pointing to a couple of missed trades that they "should have" undertaken. Moreover, participants can construct quasi-scientific underpinnings to trading strategies. If the trader ignored the Agriculture Department's fall report on soybeans, which ex-post proved to predict price movements, he will "know better" next year. (In much the same way, social scientists may offer ingenious justifications for modifications that rescue failed models.) Delusion is required, for if the individuals were accurate in forecasting their prospects - a loss, on average - they would withdraw money from the markets, and the markets would die. ${ }^{33}$

\section{Concluding remarks}

If individuals' behaviors could be observed, financial markets would offer a fruitful arena in which to identify behavioral as opposed to fully rational individual choices. The

\footnotetext{
${ }^{32}$ A useful parallel for futures markets may be the race track, with its high overhead expenses-the state takes more than 15\% of tolul wagers in most U.S. jurisdictions-and few winners. Some participants come for recreation, expecting 60 lose. Many losers, however, believe they have insights and systems that give them an edge. What are the properties of horse races that keep a flow of individuals and their monies coming to the track?

The observation that the survival of expensive markets neods explanation complements the paradox of Grossman and Stiglitz (1976): if markets are efficient, there is no incentive to gather any information; but then bow can markets incorporate all information to sustain efficiency?

${ }^{33}$ Zeckhauser and Niederhoffer (1983) present this insight using an ecological metaphor, likening the losing individual investors to the grass at the bottom of the fond chain. which must be replenished from outside the system if the arosystem is to survive. They argue further that market behavior must change over time to continue to fool the Monday moming quarterhacks.
} 
stakes are big, the players serious, the games repeated - circumstances that promote rational outcomes.

Direct verification is impossible though financial markets throw up great amounts of data; unfortunately, most of it is aggregated, and the rivulets caused by individual investor actions are lost beneath the waves and tides of market movements. In many instances, sophisticated investors ("poachers") capitalize on the poor decisions of others and in so doing restore market efficiency. A central lesson of financial economics is that the confluence of such individual actions can guide the market back to an efficient path, so that present prices reflect future prospects.

However, it is difficult to judge whether aggregate data themselves reflect rational patterns. For example, there is no clear consensus in the professional literature whether speculative bubbles reflect nonrational excesses, or rather a deviant macrophenomenon resulting from the actions of a multitude of rational individual investors. ${ }^{34} \mathrm{~A}$ consideration of the prospects of poaching helps identify those areas of financial activity where rational outcomes will fail or prevail.

We advocate a fresh strategy for investigating the behavioral underpinnings of financial phenomena: build from known traits of individual behavior to predictions about anomalies that will appear in aggregate data. We have followed this approach here, first identifying five behavioral traits - bam-door closing, expert/reliance effects, status quo bias, framing, and herding - and then outlining the implications for aggregate financial statistics, focusing on financial flows. Finally, turning to the real world, we found empirical evidence from firms' debt/equity ratios to investors' purchases of mutual funds to support our hypotheses. We hope this demonstration will encourage others to use models of individual nonrational behavior to elucidate financial market phenomena.

\footnotetext{
${ }^{34}$ Various observers have tried to explain speculative bubbles without jettisoning the assumption of full rationality on the part of individuals - soe the discussion from the Symposium on Bubbles (1990). Shiller (1989) argues that the evidence points to a phenomenon of investor psychology rather than a pathological aggregation.

Future research, we believe, may take a third tack. Given the behavioral patterns that are being documentexd in financial markets, what sorts of hubble behaviors and speculative excesses might we expect? Will markets be more or less stable than they would be with full rationality? Some behavioral assumptions would increase stability, others reduce it. For example, if individuals overreact to recent information (companed with base-rate data), the result could be excess volatility and quite possibly destabilizing speculation. On the other hand status quo bias in financial choices would be a force for greater stability. (Rational bubbles in severul models disappear if expectation formation is adaptive, i.e., nonrational.)
} 


\section{References}

Arrow, Kenneth: 1982, 'Risk perception in psychology and economics', Economic Inquiry 20, $1-9$.

Bilson, John: 1990, “'Technical” currency trading', working paper, The Chicago Corporation, Chicago, August.

Black, Fischer: 1986, 'Noise', Joumal of Finance, 41, 529-43.

Camerer, Colin: 1987, 'Do biases in probability judgment matter in markets?', American Economic Review 77, 981-997.

Chen, Nai-fu, Roll, Richard, and Stephen Ross: 1986, 'Economic forces and the stock market', Journal of Business 59, 383-403.

Dawkins, Richard: 1976, The Selish Gene. Oxford: Oxford University Press.

Dupre, J. (editor): 1987, The Latest on the Best: Essays on ewlution and optimality. Cambridge, Mass.: MIT Press.

Engel, Charles, and Hamilton, James: 1990, 'Long swings in the dollar: Are they in the data and do the markets know it?', American Economic Review 80, 689-713.

Fama, Eugene: 1970, 'Efficient capital markets: A review of theory and empirical work', Journal of Finance 25, 383-417.

Fama, Eugene: 1990, 'Efficient capital markets, II', working paper, Graduate School of Business, University of Chicago, December.

Frank, Robert: 1985, Choosing the Right Pond: Human Behavior and the Quest for Status. New York: Oxford University Press.

Friedman, Milton: 1953, Essays in Positive Economics, Chicago: University of Chicago Press.

Friedman, Benjamin: 1977, 'Financial flow variables and the short-run determination of longterm interest rates', Journal of Political Economy 85, 661-689.

Friedman, Benjamin: 1979, 'Substitution and expectation effects on long-term borrowing behavior and long-term interest rates', Journal of Money Credit and Banking 11, 131-150.

Goodman, S: 1982, 'Two technical analysts are even better than one', Euromoney (August), 85-96.

Grossman, Sanford, and Joseph Stiglitz: 1976, 'Information and competitive price systems', American Economic Review 66, 246-253.

Gultekin, M., Gultekin, B., and Penati, A.: 1989, 'Capital controls and international capital market segmentation: The evidence from the Japanese and American stock markets', Journal of Finance 44, 849-70.

Harris, Milton and Raviv, Arthur: 1991, 'The theory of capital structure', Journal of Finance 46, 297-356. 
Heath, Chip, and Amos Tversky: 1990 'Preference and belief: Ambiguity and competence in choice under uncertainty', forthcoming in Journal of Risk and Uncertainty.

Hendricks, K., and Kovenock, D.: 1989, 'Asymmetric information, information externalities, and efficiency: The case of oil exploration', Rand Journal of Economics 20, 164-82.

Hendricks, Darryll, Patel, Jayendu, and Zeckhauser, Richard: 1990, 'Hot hands in mutual funds: The persistence of performance, 1974-87', mimeo, John F. Kennedy School of Government, Harvard University.

Hirshleifer, Jack: 1971, 'The private and social value of information and the reward to inventive activity', American Economic Review 61, 561-574.

Kahneman, Daniel, and Tversky, Amos: 1979, 'Prospect theory: An analysis of decision under risk', Econometrica 47, 263-291.

Kahneman, Daniel, Slovic, Paul and Tversky, Amos : 1982, Judgment under Uncertainty: Heuristics and Biases. Cambridge: Cambridge University Press.

Kahneman, Daniel and Tversky, Amos: 1986, 'Rational choice and the framing of decisions', Journal of Business, 59, 251-78.

Kim, Yong and Stulz, René: 1988, 'The Eurobond market and corporate financial policy: A test of the clientele hypothesis', Joumal of Financial Economics 22, 189-205.

Lee, Charles, Shleifer, Andrei, and Thaler, Richard: 1991, 'Investor sentiment and the closedend fund puzzle', Journal of Finance 46, 75-110.

Leroy, Stephen: 1989, 'Efficient capital markets and martingales', Journal of Economic Literature 28, 1583-1621.

Lynch, Peter: 1989, One Up On Wall Street. New York: Simon \& Schuster.

Markowitz, Harry: 1952, 'Portfolio selection', Journal of Finance 7, 77-91.

Markowitz, Harry: 1959, Portfolio Selection: Efficient Diversification of Investments. New Haven: Yale University Press.

Merton, Robert C.: 1987a, 'A simple model of capital market equilibrium with incomplete information', Journal of Finance 42, 483-510.

Merton, Robert C.: 1987b, 'On the current state of the stock market rationality hypothesis', in S. Fischer, R. Dornbusch and J. Bossons (eds.), Macroeconomics and Finance: Essays in Honor of Franco Modigliani, pp. 93-124. Cambridge, Mass.: MIT Press.

Patel, Jayendu, Zeckhauser, Richard, and Hendricks, Darryll: 1991a, 'The rationality struggle: Illustrations from financial markets', American Economic Review 81, 232-6.

Patel, Jayendu, Zeckhauser, Richard, and Hendricks, Darryll: 1991b, 'Investment flows and performance: Evidence from mutual funds, cross-border investments, and new issues', in Rama Ramachandran and Ryuzo Sato (eds.), International Financial Markets. Cambridge: Cambridge University Press, forthcoming. 
Ritter, Jay: 1991, 'The long-run performance of initial public offerings', Journal of Finance 46, 3-27.

Ross, Stephen: 1989, 'Discussion: Intertemporal asset pricing', in S. Bhattacharya and G. M. Constantinides (eds.), Theory of Valuation, pp.85-96. Totowa, New Jersey: Rowman and Littlefield.

Samuelson, William, and Richard Zeckhauser: 1988, 'Status quo bias in decision making', Journal of Risk and Uncertainty 1, 7-59.

Scharfstein, Daniel, and Stein, Jeremy: 1990, 'Herd migration and investment', American Economic Review 80, 465-79.

Schelling, Thomas.: 1978, Micromotives and Macrobeha vior. New York: W.W. Norton and Company.

Shefrin, Hersh and Statman, Meir: 1989, 'Introducing prospect theory preferences into general equilibrium: Implications for CAPM and portfolio insurance', working paper, Leavey School of Business, Santa Clara University, July.

Sharpe, William: 1964, 'Capital asset prices: A theory of market equilibrium under conditions of risk', Journal of Finance 19, 425-42.

Shiller, Robert: 1981, 'Do stock prices move to much to be justified by subsequent changes in dividends?', American Economic Review 71, 421-435.

Shiller, Robert: 1989, Market Volatility. Cambridge, Mass.: MIT Press.

Shiller, Robert: 1990, 'Speculative prices and popular models', Joumal of Economic Perspectives 4, 55-66.

Shleifer, Andrei, and Summers, Lawrence: 1990, 'The noise trader approach to finance', Journal of Economic Perspectives 4, 19-34.

Simon, Herbert: 1957, Models of Man. New York: John Wiley and Sons. Symposium on Bubbles: 1990, Joumal of Economic Perspectives 4, 13-102.

Thaler, Richard and Ziemba, William: 1988, 'Anomalies: Parimutuel betting markets: Racetracks and lotteries', Journal of Economic Perspectives 2, $161-74$.

Tversky, Amos and Kahneman, Daniel: 1971, "The belief in the "law of small numbers", Psychological Bulletin 76, 105-10.

White, Eugene: 1990, 'The stock market boom and crash of 1929 revisited', Journal of Economic Perspectives 4, 67-84.

Zeckhauser, Richard and Niederhoffer, Victor: 1983, 'Futures markets as ecological systems: Survival? Efficiency? Rational participants', Presented at American Economic Association meetings, December 28. 